Tropical Journal of Pharmaceutical Research March 2015; 14 (3): 545-554

ISSN: $1596-5996$ (print); 1596-9827 (electronic)

(C) Pharmacotherapy Group, Faculty of Pharmacy, University of Benin, Benin City, 300001 Nigeria.

All rights reserved.

Available online at http://www.tjpr.org

Review Article

http://dx.doi.org/10.4314/tjpr.v14i3.26

\title{
Phytochemical, Toxicological and Pharmacological Studies of Asiasari Radix et Rhizoma: A Review
}

\author{
Mahesh Ramalingam and Sung-Jin Kim* \\ Department of Pharmacology and Toxicology, Metabolic Diseases Research Laboratory, School of Dentistry, Kyung Hee \\ University, Seoul 130-701, Republic of Korea \\ *For correspondence: Email: kimsj@khu.ac.kr; Tel.: +82-2-961-0868; Fax: +82-2-957-5309
}

Revised accepted: 23 January 2015

\begin{abstract}
Herba Asari and Asiasari Radix (AR) have a centuries-old history as a folk medicine in China, Korea and Japan. AR has long been used in combination with other herbs to treat cough, toothache, headache, neuralgia, aphthous stomatitis, gingivitis, chronic bronchitis, asthma and allergies. AR from three species of the genus Asarum: A. heterotropoides Fr. Schmidt var. mandshuricum (Maxim.) Kitag., A. sieboldii Miq. var. seoulense Nakai and A. sieboldii Miq are recognized as original "Asiasari Radix et Rhizoma". These species do not contain aristolochic acids (nephrotoxins present in the Asarum species) and therefore the roots of AR are recommended for use. Asiasari Radix is rich in volatile oils, phenylpropanoids, terpenoids, flavonoids, glycosides and lignins. The reported toxicological and pharmacological activities of AR, including antifungal, antimicrobial, antilisterial, antiallergic, acarcidal, larvicidal, anti-caries, anti-inflammatory, hepatoprotective, neuroprotective, cytotoxic and anticancer activities suggest its therapeutic potentials in drug discovery.
\end{abstract}

Keywords: Asarum; Asiasarum, Asiasarum heterotropoides var. mandshuricum, Asiasarum sieboldii Herba Asari, Folk medicine, Pharmacological, Toxicological

Tropical Journal of Pharmaceutical Research is indexed by Science Citation Index (SciSearch), Scopus, International Pharmaceutical Abstract, Chemical Abstracts, Embase, Index Copernicus, EBSCO, African Index Medicus, JournalSeek, Journal Citation Reports/Science Edition, Directory of Open Access Journals (DOAJ), African Journal Online, Bioline International, Open-J-Gate and Pharmacy Abstracts

\section{INTRODUCTION}

Traditional, indigenous systems of medicines are as old as human civilizations that have provided us with novel concepts and modalities for the treatment of various ailments [1]. The use of natural agents derived from fruits, vegetables, spices, legumes and cereals in traditional oriental medicine are attractive sources for developing novel therapeutics or prophylactics because of their safety, affordability, long-term use and ability to target multiple pathways [2]. In the past decades, extensive research and development have generated over $25 \%$ of the approved clinical drugs that are derived or tailored from natural products [3].
The species of genus Asarum (Aristolochiaceae) are distributed throughout Asia (65 species), and in eastern and western North America (15 species), and a single species in Europe [4]. Nowadays, the plant sources of Herba Asari are recorded as comprised of three species of the genus Asarum, namely, A. heterotropoides Fr. Schmidt var. mandshuricum (Maxim.) Kitag., $A$. sieboldii Miq. var. seoulense Nakai, and $A$. sieboldii Miq. The medicinal part of these plants in use is the root "Asiasari Radix et Rhizoma" (AR). AR is a nearly cylindrical rhizome with numerous thin and long roots, externally light brown to dark brown. The AR is called seshin in Korean, saishin in Japanese, Xixin in Chinese or 
Chinese wild ginger root in English [2]. AR has long been used in traditional Chinese and Korean medicine to treat cough, toothache, headache, neuralgia, aphthous stomatitis, gingivitis, chronic bronchitis, asthma and allergies, as well as for its anti-bacterial and analgesic effects $[5,6]$.

\section{QUALITY AND SAFETY}

The rapid popularity and demand of commercial herbal medicine has led to the indiscriminate and unscientific collection without much consideration on the quality and safety [7]. Specifically, aristolochic acid (aristolic acid; AA) containing herbs such as Aristolochia and Asarum species from the Aristolochiaceae family [8] have been prohibited for therapeutic use in Australia. However, these were not included in the toxic herb schedules in Asian countries [9]. The toxicity of Asarum is much lower than that of the Aristolochia species [9]. Asarum species contains aristolochic acids, mainly consisting of aristolochic acid I (AA-I) and aristolochic acid II
(AA-II) [10]. However, non-official species such as $A$. himalaicum Hook. f. et Thoms. Ex Klotzsch and $A$. forbesii Maxim., presented higher AAs concentrations than official species of Asiasari Radix [8,11]. Studies revealed that the toxic components in Herba Asari is greatly reduced during the preparation of the decoction [12] and the decoction of the root part of Asarum is recommended for traditional usage [9].

\section{PHYTOCHEMISTRY}

Plants produce a huge array of chemicals, numbering tens of thousands, primarily for defense against herbivores and pathogens as well as for the production of floral fragrance to attract pollinators [13]. A. sieboldii contains volatile oils, phenylpropanoids, nitrogen compounds, terpenoids and flavonoids. $A$. siebolddi var. seoulense contains volatile oils; while $A$. heterotropoides var. mandshuricum contains volatile oils, lignins, flavonoids, nitrogen compounds and sterols [14-19].

Table 1: Terpenes, flavonoids and glycosides isolated from Asiasari Radix

\begin{tabular}{|c|c|}
\hline Compound & References \\
\hline \multicolumn{2}{|l|}{ Terpenes } \\
\hline$( \pm)$-car-3-ene-2,5-dione & [16] \\
\hline$( \pm)$-asarinol A & [16] \\
\hline$( \pm)$-asarinol B & [16] \\
\hline (-)-asarinol C & [20] \\
\hline$(+)$-asarinol C & {$[20]$} \\
\hline$(+)$-asarinol D & {$[20]$} \\
\hline$\alpha$-hydroxy-p-cymene = p-Cymen-8-ol & [21] \\
\hline$\alpha$-pinene & [22] \\
\hline$\beta$-pinene & {$[21,22]$} \\
\hline$\alpha$-terpinol & [21] \\
\hline 3-carene & {$[21,22]$} \\
\hline trans-caryophyllene & [21] \\
\hline Cineol $=$ Cineole $=1,8$-cineole & [23] \\
\hline D-(+)-limonene & [22] \\
\hline Eucarvone & [21-23] \\
\hline Sabinene & [21] \\
\hline Terpinolene & [22] \\
\hline \multicolumn{2}{|l|}{ Flavonoids and their glycosides } \\
\hline 5,7-di-O- $\beta$-D-glucopyranosyl 2(R)-naringenin & [24] \\
\hline 5,7-di-O- $\beta$-D-glucopyranosyl 2(S)-naringenin & [24] \\
\hline 3',5'-dimethoxy-4'-O- $\beta$-D-glucopyranosyl-cinnamic acid & [24] \\
\hline 1-O-feruloyl- $\beta$-D-glucopyranoside & [24] \\
\hline 1-O-feruloyl- $\beta$-D-xylopyranosyl-(1 $\rightarrow 6)-\beta$-D-glucopyranoside & [24] \\
\hline 1-O-feruloyl- $\beta$-D-xylopyranosyl-(1 $\rightarrow 6)$ - $\beta$-D-glucopyranoside heptaacetate & [24] \\
\hline 1-O-p-coumaroyl- $\beta$-D-xylopyranosyl-(1-6)- $\beta$-D-glucopyranoside & [24] \\
\hline 1-O-p-coumaroyl- $\beta$-D-xylopyranosyl-(1 $\rightarrow 6)-\beta$-D-glucopyranoside heptaacetate & [24] \\
\hline
\end{tabular}


Table 2: Other compounds isolated from Asiasari Radix

\begin{tabular}{lll}
\hline Classification & Compound & References \\
\hline Alkaloids & dl-demethylcoclaurine = higenamine & {$[21]$} \\
Alkanes & n-pentadecane = Pendadecane & {$[22,23]$} \\
Alkenes & Pellitorine & {$[15]$} \\
& N-isobutyldodecatetraenamide & {$[21,23]$} \\
Lignans & Asarinin = Sesamin & {$[21,25]$} \\
& $(-)$-asarinin = (-)-sesamin & {$[16,26,27]$} \\
Phenols & Xanthoxylol & {$[25,27]$} \\
Pyrogallols & Asaricin = Myristicin & {$[22,23,26]$} \\
& Elemicin & {$[16,21]$} \\
Toluene & $3,4,5$-trimethoxytoluene & {$[26]$} \\
Anisoles & $\gamma$-asarone & {$[27]$} \\
& $3,5-$-dimethoxytoluene & {$[22,23,26]$} \\
& Estragole & {$[21,22]$} \\
Eugenol & Methyleugenol & {$[16,21-23,26]$} \\
Dioxoles & Safrole & {$[22,23,26]$} \\
Ketones & Kakoul = Kakuol & {$[26]$} \\
& Methylkakuol & {$[26]$} \\
Phytosterols & Campesterol & {$[21]$} \\
& Sitosterol & {$[21]$} \\
& Stigmasterol & {$[21]$} \\
\hline
\end{tabular}

\section{TOXICOLOGICAL PROPERTIES}

\section{Acute and subacute toxicity}

Increasing concentrations of methanol extract of AR orally administered to mice for 7 days to measure $\mathrm{LD}_{50}$ was calculated to be $3400 \mathrm{mg} / \mathrm{kg}$. There were no significant behavioral changes in the mice for $\mathbf{2 4 0}$ min following oral administration of $100 \mathrm{mg} / \mathrm{kg}$ of AR methanol extract [5]. Acute oral toxicity study of AR extract showed no mortality of mice at the doses of 1000,3000 , and $5000 \mathrm{mg} / \mathrm{kg}$ body weight [28]. In 28 days of subacute toxicity study, rats received repeated doses of AR methanol extract (50, 250 and 500 $\mathrm{mg} / \mathrm{kg}$ body weight/day) and showed no mortality [29]. Besides, no signs of toxicity, such as convulsion, vomiting, diarrhea, paralysis, breathing difficulties, bleeding, restless, irritation, and abnormal posture, were observed in AR extract-treated mice and rats in acute and subacute toxicity studies respectively $[28,29]$.

\section{Food consumption, weight changes and histopathology}

As proper intake of nutrients are essential to the physiological status of the animals, AR extract treatment did not show significant differences in food consumption, body weights and organs weights in male and female mice and rats for 14 days in acute toxicity and 28 days in subacute toxicity studies at all doses tested $[28,29]$. Organs weights revealed that the AR methanol extract did not produce organ swelling, atrophy, or hypertrophy. Moreover, gross examination of internal organs of all animals revealed no detectable abnormalities. Histopathologic evaluation did not reveal any observable damages in all the vital organs.

Table 3: Toxicological activities of the extracts from Asiasari Radix

\begin{tabular}{|c|c|c|c|}
\hline Details & Extract & Active dose & References \\
\hline $\begin{array}{l}\text { Acute toxicity } \\
\text { LD }_{50}\end{array}$ & $\begin{array}{l}70 \% \text { methanol extract, } \\
\text { chloroform-methanol }\end{array}$ & $\mathrm{LD}_{50}: 3400 \mathrm{mg} / \mathrm{kg}$ & [5] \\
\hline $\begin{array}{l}\text { Sign of toxicity } \\
\text { Mortality } \\
\text { Food consumption } \\
\text { Body weight changes } \\
\text { Organs weight changes }\end{array}$ & $\begin{array}{l}\text { soluble and insoluble } \\
\text { fractions }\end{array}$ & $\begin{array}{c}1000,3000 \text { and } 5000 \\
\mathrm{mg} / \mathrm{kg}\end{array}$ & [28] \\
\hline $\begin{array}{l}\text { Subacute toxicity } \\
\text { Mortality } \\
\text { Body weight } \\
\text { Food consumption } \\
\text { Necropsy } \\
\text { Histopathaology }\end{array}$ & $\begin{array}{c}70 \% \text { methanol extract and } \\
\text { chloroform-methanol } \\
\text { soluble and insoluble } \\
\text { fractions }\end{array}$ & $\begin{array}{c}50,250 \text { and } 500 \\
\mathrm{mg} / \mathrm{kg} / \text { day }\end{array}$ & [29] \\
\hline
\end{tabular}


Thus, it can be suggested that AR extract is virtually nontoxic in mice and rats $[28,29]$.

\section{Blood chemistry}

Blood is an important index and the parameters usually measured are haemoglobin (HB), red blood cell (RBC) count, white blood cell (WBC) count, and differential leukocyte count. These blood indices were all measured after 28 days of oral administration without any significant alterations from the control values, again corroborating the wide safety margin of the AR methanol extract. Biochemical parameters are an important marker to evaluate the organs and cellular functions. The results obtained from the biochemical evaluation, showed no significant difference between all doses administered and between sexes [29]. Among the evaluated parameters, alanine aminotransferase (ALT), aspartate aminotransferase (AST), and alkaline phosphatase (ALP), total and conjugated bilirubin, total protein, albumin, globulin, and $A / G$ ratio are considered as liver function markers because several reports of liver toxicity are related to the use of phytotherapeutic products. Any marked necrosis of the liver cells can lead to a significant change of these parameters in the blood serum. No changes were observed in these parameters showed that the AR methanol extract has no adverse effect on the hepatocytes [29].

Kidney toxicity has also been reported after use of phytotherapeutic products. In this case, urea, creatinine, and electrolyte determinations are vital, as these substances are markers of kidney function. No significant differences in the parameters were detected. AR methanol extract did not cause any effect on kidney function [29]. Moreover, glucose was estimated as a marker for pancreatic damage. Total cholesterol, triglycerides, and HDL-cholesterol were determined to evaluate whether the AR methanol extract has hypo- or hyperlipidemic properties. Inorganic phosphorus and calcium were measured for bone-demineralization properties. There were no significant differences observed in the above biochemical parameters. Collectively, these data demonstrated that the methanol extract of AR has a high margin of drug safety [29].

\section{PHARMACOLOGICAL PROPERTIES}

Antifungal, antimicrobial and anti-listerial activities

Colletotrichum orbiculare (Berk \& Mont) Arx is the causal agent of anthracnose which is probably the most destructive disease of cucurbits in warm seasons with frequent rain. The infection of cucumber leaves by $C$. orbiculare and anthracnose development was reduced as the concentrations of kakuol and chlorothalonil gradually increased. Kakuol did not show any phytotoxic symptoms on cucumber leaves suggesting that the kakuol could be developed as an agricultural fungicide for the control of plant diseases [30]. The methanolic extract of AR showed strong antimicrobial activity against methicillin-resistant Staphylococcus aureus (MRSA) KCCM 11812, 40510 and $S$. aureus ATCC 25923 [31].

Listeria monocytogenes is a food-borne pathogen that causes listeriosis, a potentially lethal disease with symptoms including febrile gastroenteritis, septicemia, meningitis and spontaneous abortion. The seven compounds such as ( \pm )-car-3-ene-2,5-dione, (-)-asarinin, (-)sesamin, $\mathrm{Y}$-asarone, pellitorine, $( \pm)$-asarinol $\mathrm{A}$, and methyleugenol from $\mathrm{CH}_{2} \mathrm{Cl}_{2}$ soluble fraction of the AR methonal extract were reported for their strongest anti-listerial activity against five $L$. monocytogenes strains and could be utilized as effective resources for the development of antilisterial agents [32].

\section{Anti-allergic activity}

AR inhibited the stimulatory effect of LPS and/or T cell-driven IL-4-dependent immunoglobulin (Ig) $\mathrm{E}(\mathrm{IgE})$ synthesis in the U266B1 myeloma cells and mice whole spleen cells. However, AR did not affect IgE production in normal U266B1 cells suggest that $A R$ could present an approach for the treatment of allergic disease [33]. The methanolic extract of AR containing methyleugenol, elemicin, $\gamma$-asarone, (-)-asarinin, and (-)-sesamin has also been reported for antiallergic effects. Elemicin and (2E,4E,8Z,10E)-Nisobutyl-2,4,8,10-dodecatetraenamide were found to exhibit an inhibitory action on 5lipoxygenase (5-LOX) from RBL-1 cells. 3',4'Dimethoxycinnamaldehyde and xanthoxylol potently reduced the contractile response of guinea pig ileal strips to $\mathrm{LTD}_{4}$ [27].

\section{Acaricidal and larvicidal activities}

House dust mite, Dermatophagoides farinae (Hughes), causes major allergic diseases, including asthma, allergic rhinitis, and atopic dermatitis. Petroleum ether extract from AR was toxic to $D$. farinae adults [34]. Methyleugenol, one congener of eugenol which is known to be toxic to $D$. farinae [35] was weaker than AR essential oil [34]. Mosquitoes are prevalent worldwide and are common and serious disease 
vectoring insect pests. The toxicity of several compounds isolated from AR steam distillate to third-instar larvae of Culex pipiens pallens Coquillett, Aedes aegypti (L.), and Ochlerotatus togoi Theobald has been reported [36]. Methyleugenol, a-asarone, pentadecane, (-)asarinin and pellitorine isolated from AR were effective against $C$. p. pallens larvae resistant to various insecticides [37]. The methanol extract of AR showed the strongest larvicidal activity against larvae of the house fly, Musca domestica (L.) [38]. Eucarvone and safrole extracted from $A R$ were reported for their significant insecticidal activities against the rice weevil Sitophilus oryzae (L.), a most widespread and destructive primary insect pest of stored cereals [39].

\section{Anti-caries activity}

Dental caries is the most common chronic oral disease. Streptococcus mutans is the most important bacterium in the formation of dental plaque and dental caries. Ethanol and aqueous extracts of $A$. sieboldii reduced the acid production and inhibited the growth and adhesion of $S$. mutans. The synthesis of water-insoluble glucan by crude GTFase was also suppressed during $A$. sieboldii treatment [40].

\section{Anti-inflammatory, antitussive and anti- nociceptive activities}

Inflammation is a multi-step process that is mediated by activating inflammatory and immune cells. In the carrageenin-induced rat paw edema test, the AR extract had anti-inflammatory action and the effects were similar to that of ibuprofen [41]. The water $(0.8,1.6 \mathrm{~g} / \mathrm{kg})$ and ethanol $(0.91$, $1.82 \mathrm{~g} / \mathrm{kg}$ ) extracts of AR significantly reduced the weight of mouse ear edema against xylene induced inflammation [42]. The essential oil of AR may inhibit the proliferation of granuloma induced by implantation of cotton pellets in rats and the results suggests that this action might be related to the reduction of blood serum zinc [43]. Biologically active constituents isolated from AR such as (-)-sesamin, (2E,4E,8Z,10E)-N-(2methylpropyl)dodeca-2,4,8,10-tetraenamide,

kakuol, and 3,4,5-trimethoxytoluene $(=1,2,3-$ trimethoxy-5-methylbenzene) have been reported to possess inhibitory activity on lipopolysaccharides (LPS)-induced nitric oxide (NO) production in BV-2 microglial cells [26]. The compounds: methylkakuol, 3,5-dimethoxytoluene (=1,3-dimethoxy-5-methylbenzene), safrole, asaricin, methyleugenol, and (-)-asarinin showed negligible inhibitory activities [26]. The essential oils in the AR also possess considerable NOscavenging activity [44].
Both histamine- and bradykinin-induced guinea pig ileum contractions were considerably inhibited, suggesting that the AR extract could interfere with the binding of histamine and bradykinin to its corresponding receptors, thereby inhibiting pain and inflammation reactions [41]. Higenamine and methyleugenol mainly play important roles in the antitussive action of AR. It has been clarified that higenamine is an adrenergic $\beta$-stimulant and that methyleugenol relaxes directly the tracheal muscle [14].

A hot-plate test to clarify the supra-spinal action of ethanol extract of AR has been reported and these results suggest that $A R$ may stimulate $\mathrm{GABA}_{A}$ receptors at postsynaptic sites rather than affect the supra-spinal nervous system. AR ethanol extract suppresses tonic pain induced by the intraplantar injection of formalin and $\mathrm{N}$ methyl-D-aspartate (NMDA)-induced pain-related responses through activation of $\gamma$-aminobutyric acid (GABA) receptors [45]. Mice administered with water extracts of AR delayed the latency times in the hot plate test than ethanol extracts of $\mathrm{AR}$ [42]. Methyleugenol inhibited $\mathrm{Ca}^{2+}$ influx by directly inhibiting nerve depolarization via the stimulation of postsynaptic GABAA receptors in the dorsal horn, preventing hyperalgesia [45]. Methyleugenol (1-allyl-3,4-dimethoxybenzene), also has antinociceptive effect on the second phase of formalin-induced nociception without affecting the first phase [46].

Acetic acid-induced mouse writhing assay is used for detecting peripheral analgesia whereas tail-flick is more sensitive in centrally acting analgesics. Results indicate that some active principles of AR methanol extract could bind to the $\mu, K$ and $\delta$ opioid receptors. The methanol extract of AR contains morphine-like component and other peripherally acting principles. AR extracts are more potent in the anti-nociceptive actions compared to aspirin [41].

\section{Hair growth promoting activity}

It is important to develop novel therapies that prevent hair loss and enhance hair growth. Ethanol extract of AR has outstanding hair growth-promoting effects in rodent models. In addition, the AR extract regulates the expression of growth factors in dermal papilla (DP) cells that are cultured in vitro. Various cytokines and growth factors play important roles in hair growth control. Insulin growth factor-1 (IGF-1), vascular endothelial growth factor (VEGF), keratinocyte growth factor (KGF), and hepatocyte growth factor (HGF) have stimulatory effects on hair follicle growth, whereas epidermal growth factor 
(EGF) and tranforming growth factor- $\beta$ (TGF- $\beta$ ) has inhibitory effects on hair follicle growth. It is noteworthy that the AR extract has the potential to increase the expression of VEGF in DP cells. But, the AR extract did not show an inhibitory effect on the expression of 5a-reductase [47].

\section{Anti-melanogenesis activity}

Transcriptional regulation of melanogenic proteins is primarily dependent on the expression of microphthalmia-associated transcription factor (MITF), which is a master transcriptional regulator of key melanogenic enzymes. The suppressive activity of AR on melanogenesis is linked to down-regulation of MITF-tyrosinase expression signaling pathways and not due to the direct down-regulation of tyrosinase activity. Activation of extracellular signal-regulated kinase (ERK) and phosphoinositide 3-kinase/protein kinase B (PI3K/Akt) signaling reduced melanin synthesis through MITF degradation and inhibition, respectively. AR inhibits pigmentation by indirectly regulating tyrosinase via ERK activation and subsequent MITF down-regulation [6]. AR also strongly inhibited tyrosinase activity, tyrosinase-related protein (TRP)-1, dopachrome tautomerase (Dct) and MITF and leads to decreased melanin synthesis in a-melanocyte stimulating hormone $(\alpha-\mathrm{MSH})$-stimulated B16F10 melanoma cells [48].

\section{Vascular inflammatory conditions}

Nuclear DNA-binding protein high mobility group box 1 (HMGB1) protein acts as a late mediator of severe vascular inflammatory conditions, such as sepsis and septic shock [49]. Extracellular HMGB1, released from necrotic cells and/or from inflammation-stimulated immune cells, functions as a pro-inflammatory cytokine and elicits proinflammatory responses of macrophages and endothelial cells [50]. The epi-sesamin isolated from AR treatment resulted in marked inhibition of cecal ligation and puncture (CLP)-induced release of HMGB1 in septic mice and LPSinduced HMGB1 in HUVECs.

Moreover, epi-sesamin resulted in significant inhibition of toll-like receptor 4 (TLR4) expression without affecting cell viability in HUVECs. Activation of nuclear factor-KB (NF-KB) and ERK1/2 increased by HMGB1 were significantly reduced by epi-sesamin. Mice pretreated with epi-sesamin survived longer after CLP than untreated mice suggests that epi-sesamin suppressed HMGB1 and of HMGB1-mediated inflammatory responses to be a therapeutic strategy for management of sepsis and septic shock [49].

\section{Hepatoprotective and anti-HPV activities}

The aqueous extract of AR decreased markedly the increase of serum and liver ALT, AST, lactate dehydrogenase (LDH) and ALP activities caused by benzo[a]pyrene (BP) in rats. The increase of serum total cholesterol and phospholipid contents in BP-injection were also decreased by treatment of the aqueous extract of AR. From these results, the aqueous extracts of AR have significant liver-protective effects against BPinduced hepatotoxicity [51]. The aqueous extracts from AR are also effective on antiHuman papillomavirus [52].

\section{Neuroprotective activities}

An increase in acetylcholine levels induced by decreased activity of acetylcholinesterase following AR extract treatment may cause activation of acetylcholine receptors, thereby stimulating extracellular signal-regulated kinase (ERK). The prolongation of survival time by $A R$ extracts following sodium nitrite $\left(\mathrm{NaNO}_{2}\right)$ administration could be regarded as an increase of learning and memory possibly by increasing acetylcholine release or synthesis [5]. AR enhances the transcripts neurotrophins such as nerve growth factor (NGF), brain-derived neurotrophin factor (BDNF) and neurotrophin-3 (NT-3) in C2C12 cells-cultured medium and stimulate neurite outgrowth and stabilized the neurite formation in PC12D cells [53].

The AR methanol extract and its fractions showed decreasing working and reference errors and time spent collecting all baits, suggesting these fractions of AR significantly increase memory formation. In the passive avoidance test with mouse and rats, administration of AR caused a considerable increase in memory activity indicating that species differences are minimal in terms of memory formation by $A R$ extracts. AR extracts have the ability to stimulate the tyrosine kinase activity of hippocampal insulin receptor in mouse as well as in rat, subsequently cause the activation of ERK, which eventually leads to the activation of subsequent signal transduction pathways in the hippocampus, thereby inducing memory enhancement later [5].

AR extracts has significantly inhibited the cell death induced by a-amino-3-hydroxy-5-methyl-4isoxazolepropionic acid (AMPA) in PC12 and glial cells. Moreover, with a grease-gap recording techniques, the methanol extract and methanol fraction obtained from the chloroform-methanol insoluble fraction of AR contains active components responsible for the inhibition of AMPA receptors [54]. 


\section{Cytotoxic and anticancer activities}

$A R$ induced apoptosis preceded by a tight cell cycle arrest in the G2/M phase suggests that AR prevents the growth of HCT-116 cells. AR activated the caspases involved in the intrinsic (caspase-9) and extrinsic (caspase-8) apoptotic pathways and further elevates the expression of p53. Thus, the active p53 upregulates the expression of pro-apoptotic proteins, such as Bax and p53 upregulated modulator of apoptosis (PUMA), thereby inhibiting the anti-apoptotic survival protein $\mathrm{Bcl}-2$ [2]. The ethyl acetate soluble fraction of AR has been found to exhibit cytotoxic activity against human cancer cell lines such as A549 (human lung carcinoma), SK-OV-3 (human ovary adenocarcinoma), and SK-MEL-2 (human malignant melanoma) [55]. The ethanol extract of AR significantly enhanced the sensitivity to paclitaxel, which is a MDR1 substrate, of HeLa cells [47]. Moreover, It did not affect the sensitivity to 5-fluorouracil, which is not a MDR1 substrate [56].

The three allylbenzens, methyleugenol, elemicin and $\gamma$-asaron exhibited a suppression of the 2amino-3,4-dimethylimidazo[4,5-f]quinoline (MeIQ)-induced SOS response in S. typhimurium TA1535/pSK1002 umu test [57] suggests that these compounds inhibited metabolism of MelQ by CYP1A2. From this, having a methoxy group at C-2 ( $\gamma$-asaron) than at C-3 (elemicin, methyleugenol) position in these compounds is more effective for the suppression of SOS response [58]. Methyleugenol and $y$-asaron have an inhibitory activity of Epstein-Barr virus early antigen (EBV-EA) activation suggests that these compounds might be antitumur promoters. Two lignans (-)-asarinin and xanthoxylol extracted from the n-hexane extract of $A R$ and aqueous decoction of Shouseiryu-to exhibited strongest inhibitory effects on EBV-EA activation [25].

Table 4: Neuroprotective activities of Asiasari Radix

\begin{tabular}{|c|c|c|c|}
\hline Details & Extract/compound & Active dose & References \\
\hline $\begin{array}{l}\text { Hippocampal cholinesterase activity } \\
\text { Hypoxia induced by } \mathrm{NaNO}_{2}\end{array}$ & $\begin{array}{l}70 \% \text { methanol extract and } \\
\text { chloroform-methanol soluble } \\
\text { and insoluble fractions }\end{array}$ & $\begin{array}{l}\text { (100 mg for hypoxia } \\
\text { model) }\end{array}$ & [5] \\
\hline $\begin{array}{l}\text { Activities on neurite outgrowth and } \\
\text { stabilization of neurite formation }\end{array}$ & Crude extraction & $0.4 \mathrm{mg} / \mathrm{ml}$ & {$[53]$} \\
\hline $\begin{array}{l}\text { The eight-arm radial maze test, passive } \\
\text { avoidance test }\end{array}$ & & $10 \mathrm{mg} / \mathrm{kg}$ & [5] \\
\hline $\begin{array}{l}\text { Activities on tyrosine phosphorylation of } \\
\text { insulin receptor and ERK }\end{array}$ & $70 \%$ methanol extract and & $10 \mathrm{mg} / \mathrm{kg}$ & [5] \\
\hline Cell viability against AMPA & chloroform-methanol soluble & $10 \mu \mathrm{g} / \mathrm{ml}$ & {$[54]$} \\
\hline Cell viability against AMPA & & $10 \mu \mathrm{g} / \mathrm{ml}$ & \\
\hline $\begin{array}{l}\text { Electrophysiological experiments } \\
\text { against AMPA } \\
\text { (Grease-gap recording) }\end{array}$ & & $10 \mu \mathrm{g} / \mathrm{ml}$ & \\
\hline
\end{tabular}

Table 5: Cytotoxic and anti-cancer activities of Asiasari Radix

\begin{tabular}{|c|c|c|c|}
\hline Details & Extract/compound & Active dose & References \\
\hline $\begin{array}{l}\text { The cell cycle arrest in the G2/M phase } \\
\text { Expressions of Bax/Bcl-2, p53 and } \\
\text { activated caspases }\end{array}$ & $70 \%$ ethanol extract & $20 \mu \mathrm{g} / \mathrm{ml}$ & [2] \\
\hline The cytotoxic activity & Ethyl acetate soluble fraction & $\begin{array}{l}\mathrm{ED}_{50}: 8.6 \text { to } 10.2 \\
\mu \mathrm{g} / \mathrm{ml}\end{array}$ & {$[55]$} \\
\hline Activities on paclitaxe and MDR1 & $\begin{array}{l}70 \% \text { ethanol extract } \\
\text { Aqueous extract }\end{array}$ & $>100 \mu \mathrm{g} / \mathrm{ml}$ & {$[47,56]$} \\
\hline $\begin{array}{l}\text { Activities against MelQ- MelQ-induced } \\
\text { SOS resonse in S. typhimurium } \\
\text { TA1535/pSK1002 umu test }\end{array}$ & $\begin{array}{l}\text { methyleugenol, elemicin and } \gamma- \\
\text { asaron }\end{array}$ & $0.4 \mathrm{mM}$ & {$[57,58]$} \\
\hline $\begin{array}{l}\text { Inhibitory activity of Epstein-Barr virus } \\
\text { early antigen (EBV-EA) activation }\end{array}$ & methyleugenol and $\gamma$-asaron & $100 \mu \mathrm{g} / \mathrm{ml}$ & {$[25]$} \\
\hline
\end{tabular}




\section{CONCLUSION}

In this review, we have summarized the existing uses of AR and research on its phytochemistry, toxicology, and pharmacology. The official species of AR does not contain detectable amount of aristolochic acids. AR contains volatile oils, phenylpropanoids, terpenoids, flavonoids, glycosides and lignins. AR extracts are fairly nontoxic based on oral toxicity studies. Pharmacological studies reveal its therapeutic potentials in the treatment of inflammation and pain and also exerts anti-fungal, anti-allergic, larvicidal, acardicidal, anti-caries, anti-tussive, anti-nociceptive, hair growth promoting, antimelanogenesis, vascular, hepatoprotective, neuroprotective and anti-cancer activities. Available research findings indicate that $A R$ is an important medicinal component of remedies for the treatment of many diseases. It is reasonable to propose that some leading bioactive compounds (terpenoids and phenolic compounds) are involved in its pharmacological activities and thus presents a new class of drugs in drug discovery.

\section{ACKNOWLEDGEMENT}

This work was supported by a grant from Kyung Hee University in 2013-2014 (no. KHU20131115) and Basic Science Research Program through the National Research Foundation of Korea (NRF) which is funded by the Korean Ministry of Education, Science and Technology (no. 2013R1A1A2006613).

\section{REFERENCES}

1. Agrawal J, Pal A. Nyctanthes arbor-tristis Linn-A critical ethnopharmacological review. I Ethnopharmacol 2013; 146: 645-658.

2. Oh SM, Kim J, Lee J, Yi JM, Oh DS, Bang OS, Kim NS. Anticancer potential of an ethanol extract of Asiasari radix against HCT-116 human colon cancer cells in vitro. Oncol Lett 2013; 5: 305-310.

3. Khaled M, Jiang Z-Z, Zhang L-Y. Deoxypodophyllotoxin: A promising therapeutic agent from herbal medicine. J Ethnopharmacol 2013; 149: 24-34.

4. Kelly L. Phylogenetic relationships in Asarum (Aristolochiaceae) based on morphology and ITS sequences. Am J Bot 1998; 85: 1454-1467.

5. Han Y, Kim S-J. Memory enhancing actions of Asiasari radix extracts via activation of insulin receptor and extracellular signal regulated kinase (ERK) I/II in rat hippocampus. Brain Res 2003; 974: 193-201.

6. Jang JY, Lee JH, Shin HK, Choi YH, Lee JD, Choi BT. Partially purified Asiasari radix inhibits melanogenesis through extracellular signal-regulated kinase signaling in B16F10 cells. Int $\mathrm{J} \mathrm{Mol} \mathrm{Med} \mathrm{2010;} 25$ : 287-292.

7. Khanam Z, Singh $O$, Singh R, Bhat IUH. Safed musli (Chlorophytum borivilianum): A review of its botany, ethnopharmacology and phytochemistry. J Ethnopharmacol 2013; 150: 421-441.

8. Jong T-T, Lee M-R, Hsiao S-S, Hsai J-L, Wu T-S, Chiang $S T$, Cai S-Q. Analysis of aristolochic acid in nine sources of Xixin, a traditional Chinese medicine, by liquid chromatography/atmospheric pressure chemical ionization/tandem mass spectrometry. J Pharm Biomed Anal 2003; 33: 831-837.

9. Kim EJY, Chen Y, Huang JQ, Li KM, RazmovskiNaumovski V, Poon J, Chan K, Roufogalis $B D$, McLachlan AJ, Mo S-L, et al. Evidence-based toxicity evaluation and scheduling of Chinese herbal medicines. J Ethnopharmacol 2013; 146: 40-61.

10. Guo L, Yue $H$, Cai Z. A novel pre-column fluorescent derivatization method for the sensitive determination of aristolochic acids in medicinal herbs by highperformance liquid chromatography with fluorescence detection. J Pharm Biomed Anal 2010; 53: 37-42.

11. Yamasaki K, Tagami T, Kawaguchi M, Okihashi $M$, Takatori S, Sakagami Y, Sekita S, Satake M. Simple and rapid analysis of aristolochic acid contained in crude drugs and Kampo formulations with solidphase extraction and HPLC photodiode-array detection. J Nat Med 2009; 63: 451-458.

12. Cai $S-Q, L i$ J. Species systematization and quality evaluation of commonly used Chinese traditional drugs. Beijing: Beijing Medical University Press. 2001. p.1-108

13. Tan KH, Nishida R. Methyl eugenol: its occurrence, distribution, and role in nature, especially in relation to insect behavior and pollination. J Insect Sci 2012; 12: 56.

14. Kosuge T, Yokota M, Nukaya H, Gotoh Y, Nagasawa M. Studies on antitussive principles of Asiasari radix. Chem Pharm Bull 1978; 26: 2284-2285.

15. Yasuda I, Takeya K, Itokawa H. Structures of amides from Asiasarum heterotropoides MAEK. var. mandshuricum MAEK. Chem Pharm Bull 1981; 29: 564-566.

16. Hashimoto $K$, Katsuhara $T$, Itoh $H$, Ikeya $Y$, Okada $M$, Mitsuhashi $H$. Monoterpenes from asiasari radix from Asiasarum sp. Phytochemistry 1990; 29: 3571-3574.

17. Stuppner H, Ganzera M. Determination of safrole in different Asarum species by headspace gas chromatography. Chromatographia 1998; 47: 685688.

18. Opitz $M$, Pachaly $P$, Sin KS. New polar ingredients from Asiasarum sieboldii. Pharmazie 1999; 54: 218-223.

19. Cai $S Q$, Yu J, Wang $X$, Wang RQ, Ran FX, Shang MY, Cui JR, Komatsu K, Namba T. Cytotoxic activity of some Asarum plants. Fitoterapia 2008; 79: 293-297.

20. Hashimoto K, Katsuhara T, Niitsu K, Ikeya Y, Hayashi K, Fujita T. Enantioexcess monoterpenes from roots of 
Asiasarum sieboldi. Phytochemistry 1994; 35: 969973.

21. Zhou RH. Resource Science of Chinese Medicinal Materials. Beijing: China Medical \& Pharmaceutical Sciences Press. 1993. p.202-211.

22. Oka Y, Otsuki K, Katagi M, Tsuchihashi H. [Study of components in crude drugs by head space gas chromatography. I. Components of Asiasari radix]. Yakugaku Zasshi 1991; 111: 234-240.

23. Zhang F, Wang $L X$, Luo Q, Xiao HB, Liang XM, Cai $S Q$. [Analysis of volatile constituents of root and rhizome of Asarum heterotropoides Fr. var. mandshuricum (Maxim.) Kitag. by gas chromatography-mass spectrometry]. Se Pu 2002; 20: 467-470.

24. Hashimoto K, Katsuhara T, Niitsu K, Ikeya Y, Okada M, Mitsuhashi $H$. Two glycosides from roots of Asiasarum sieboldi. Phytochemistry 1992; 31: 2477 2480.

25. Takasaki M, Konoshima T, Yasuda I, Hamano T, Tokuda H. Inhibitory effects of shouseiryu-to on two-stage carcinogenesis. II. Anti-tumor-promoting activities of lignans from Asiasarum heterotropoides var. mandshuricum. Biol Pharm Bull 1997; 20: 776-780.

26. Han AR, Kim HJ, Shin M, Hong M, Kim YS, Bae H. Constituents of Asarum sieboldii with inhibitory activity on lipopolysaccharide (LPS)-induced NO production in BV-2 microglial cells. Chem Biodivers 2008; 5: 346-351.

27. Hashimoto K, Yanagisawa T, Okui Y, Ikeya Y, Maruno M, Fujita T. Studies on anti-allergic components in the roots of Asiasarum sieboldi. Planta Med 1994; 60 : 124-127.

28. Ramesh T, Lee K, Lee H, Kim S. Acute oral toxicity study of Asiasari radix extract in mice. Int $J$ Toxicol 2007; 26: $247-251$.

29. Ramesh T, Lee K, Lee HW, Kim SJ. Subacute toxicological evaluation of Asiasari radix methanol extract. Drug Chem Toxicol 2009; 32: 243-251.

30. Lee JY, Moon SS, Hwang BK. Isolation and antifungal activity of kakuol, a propiophenone derivative from Asarum sieboldii rhizome. Pest Manag Sci 2005; 61: 821-825.

31. Ji Y-j, Lee J-w, Lee I-s. Antimicrobial effect of medicinal plants against methicillin-resistant Staphylococcus aureus (MRSA). J Life Sci 2007; 17: 412-419.

32. Oh J, Hwang IH, Kim DC, Kang SC, Jang TS, Lee SH, Na M. Anti-listerial compounds from Asari Radix. Arch Pharm Res 2010; 33: 1339-1345.

33. Kim H-M, Moon Y-S. Asiasari radix inhibits immunoglobulin $E$ production on experimental models in vitro and in vivo. Immunopharmacol Immunotoxicol 1999; 21: 469-481.

34. Wu H, Li J, Zhang F, Li L, Liu Z, He Z. Essential oil components from Asarum sieboldii Miquel are toxic to the house dust mite Dermatophagoides farinae. Parasitol Res 2012; 111: 1895-1899.

35. Kim EH, Kim HK, Ahn YJ. Acaricidal activity of clove bud oil compounds against Dermatophagoides farinae and Dermatophagoides pteronyssinus (Acari: Pyroglyphidae). J Agric Food Chem 2003; 51: 885889.

36. Perumalsamy H, Kim NJ, Ahn YJ. Larvicidal activity of compounds isolated from Asarum heterotropoides against Culex pipiens pallens, Aedes aegypti, and Ochlerotatus togoi (Diptera: Culicidae). J Med Entomol 2009; 46: 1420-1423.

37. Perumalsamy H, Chang KS, Park C, Ahn YJ. Larvicidal activity of Asarum heterotropoides root constituents against insecticide-susceptible and -resistant Culex pipiens pallens and Aedes aegypti and Ochlerotatus togoi. J Agric Food Chem 2010; 58: 10001-10006.

38. Seo SM, Park IK. Larvicidal activity of medicinal plant extracts and lignan identified in Phryma leptostachya var. asiatica roots against housefly (Musca domestica L.). Parasitol Res 2012; 110: 1849-1853.

39. Kim J, Park IK. Fumigant toxicity of Korean medicinal plant essential oils and components from Asiasarum sieboldi root against Sitophilus oryzae L. Flavour Frag J 2008; 23: 79-83.

40. Yu HH, Seo SJ, Hur JM, Lee HS, Lee YE, You YO. Asarum sieboldii extracts attenuate growth, acid production, adhesion, and water-insoluble glucan synthesis of Streptococcus mutans. J Med Food 2006; 9: 505-509.

41. Kim S-J, Gao Zhang C, Taek Lim J. Mechanism of antinociceptive effects of Asarum sieboldii Miq. Radix: potential role of bradykinin, histamine and opioid receptor-mediated pathways. J Ethnopharmacol 2003; 88: 5-9.

42. Xiong $Y$, Jing $Y$, Shang $M$, Li C, Ye J, Wang X, Cai S. [Anti-inflammatory and anti-nociceptive effects in mice of water and ethanol extracts of roots and rhizomes of Asarum heterotropoides var. mandshuricum]. Zhongguo Zhong Yao Za Zhi 2009; 34: 2252-2257.

43. Hong C, Qian L, Xie W, Yan L. [Relationship between serum level of zinc and copper and inhibitory effect of herba Asari oil on proliferation of granuloma induced by implantation of cotton pellets in rats]. Zhongguo Zhong Yao Za Zhi 1992; 17: 236-238, inside backcover.

44. Yokozawa $T$, Chen CP. Evidence suggesting a nitric oxide-scavenging activity for traditional crude drugs, and action mechanisms of Sanguisorbae Radix against oxidative stress and aging. J Am Aging Assoc 2001; 24: 19-30.

45. Suzuki Y, Yuzurihara $M$, Hibino $T$, Yano $S$, Kase $Y$. Aqueous extract of Asiasari radix inhibits formalininduced hyperalgesia via NMDA receptors. J Ethnopharmacol 2009; 123: 128-133.

46. Yano S, Suzuki Y, Yuzurihara M, Kase Y, Takeda S, Watanabe S, Aburada $M$, Miyamoto $K$. Antinociceptive effect of methyleugenol on formalininduced hyperalgesia in mice. Eur J Pharmacol 2006; 553: 99-103.

Trop J Pharm Res, March 2015; 14(3): 553 
47. Rho S-S, Park S-J, Hwang S-L, Lee M-H, Kim CD, Lee I$H$, Chang S-Y, Rang M-J. The hair growth promoting effect of Asiasari radix extract and its molecular regulation. J Dermatol Sci 2005; 38: 89-97.

48. Jang JY, Kim HN, Kim YR, Kim BW, Choi YH, Choi BT. Studies of inhibitory mechanism on melanogenesis by partially purified Asiasari radix in $\alpha-M S H$ stimulated B16F10 melanoma cells. J Life Sci 2010; 20: 1617-1624.

49. Lee W, Ku SK, Kim JA, Lee T, Bae JS. Inhibitory effects of epi-sesamin on HMGB1-induced vascular barrier disruptive responses in vitro and in vivo. Toxicol Appl Pharmacol 2013; 267: 201-208.

50. Andersson U, Tracey KJ. HMGB1 is a therapeutic target for sterile inflammation and infection. Annu Rev Immunol 2011; 29: 139-162.

51. Cho E-J, Yoon S-H. Protective effect of Asiasari radix on rat liver. J Korean Soc Hygienic Sciences 1999; 5 : 85-91.

52. Deng Y, Feng Y, Sun J, Zhou D, Yang L, Lai J. [Study on anti-HPV activity of Asarum heterotropoides]. Zhong Yao Cai 2004; 27: 665-667.

53. Uezato T, Sato E, Miura N. Screening of natural medicines that efficiently activate neurite outgrowth in
PC12 cells in C2C12-cultured medium. Biomed Res 2012; 33: 25-33.

54. Han Y, Kwon EH, Kim S-J. Protection of brain cells against AMPA-induced damage by Asiasari radix extracts. Phytother Res 2003; 17: 882-886.

55. Park JD, Baek NI, Lee YH, Kim Sl. Isolation of a cytotoxic agent from asiasari radix. Arch Pharm Res 1996; 19: 559-561.

56. Takara K, Horibe S, Obata Y, Yoshikawa E, Ohnishi N, Yokoyama T. Effects of 19 herbal extracts on the sensitivity to paclitaxel or 5-fluorouracil in HeLa cells. Biol Pharm Bull 2005; 28: 138-142.

57. Miyazawa M, Kohno G. Suppression of chemical mutagen-induced SOS response by allylbenzen from Asiasarum heterotropoides in the Salmonella typhimurium TA1535/PSK1002 umu test. Nat Prod Res 2005; 19: 29-36.

58. Miyazawa M, Kohno G, Okuno Y, Oda Y. Suppression of MeIQ-induced SOS response by allylbenzenes from Asiasarum heterotropoides in the Salmonella typhimurium OY1001/1A2 umu test. Nat Prod Res 2006; 20: 671-675. 